\title{
Fungsi Asas Kesetaraan Profesi \\ Terhadap Pengembangan Figur Hukum Keperawatan \\ Dalam Sistem Hukum Kesehatan
}

\author{
Arrie Budhiartie, Muh Nasser \\ nasserkelly@yahoo.com \\ Program Studi Doktor Ilmu Hukum Fakultas Hukum \\ Universitas Sriwijaya, Palembang
}

\begin{abstract}
Abstrak:
Asas hukum, merupakan suatu bagian dari tatanan sistem hukum yang selalu ada di dalam maupun di balik keberadaan sistem hukum itu sendiri. Asas hukum memberikan arah terhadap lahirnya perumusan berbagai kaedah hukum dan kaedah perilaku, sekaligus berfungsi sebagai suatu batu uji terhadap keabsahan suatu kaedah hukum. Demikian halnya dengan hukum keperawatan, melalui keberadaan UU Nomor 38 Tahun 2014 tentang Keperawatan, penetapan asas-asas hukum di dalamnya tidaklah terlepas dari nilai-nilai etis yang menjadi karakteristik khusus pelayanan kesehatan keperawatan. Salah satu asas hukum tersebut adalah asas otonomi profesi yang menjadi landasan filsafati pendukung asas kesetaraan yang menjiwai keberadaan UU Keperawatan. Asas otonomi memberikan landasan terbentuknya kaedah-kaedah hukum yang memberikan perlindungan terhadap kebebasan dalam menjalankan fungsi-fungsi kolaboratif, komplementer, dan mandiri keperawatan berdasarkan wewenang profesinya. Asas otonomi ini diharapkan mampu mengembangkan sistem hukum kesehatan yang berkeadilan profetik dalam mendukung terwujudnya tujuan pembangunan kesehatan nasional.
\end{abstract}

Kata Kunci : Asas otonomi, asas akuntabalitas, figur hukum keperawatan, perawat

\section{A. Latar Belakang dan Permasalahan}

Kesehatan merupakan salah satu aspek kehidupan yang telah diakui merupakan bagian yang tidak terpisahkan dari kesejahteraan manusia. Tanpa kesehatan maka kualitas seseorang akan dirasakan terganggu dalam menjalankan seluruh aktifitas kehidupan sosial dan ekonomi dalam masyarakat. Oleh karena itu kesehatan telah diakui sebagai bagian dari suatu hak asasi manusia yang dicantumkan di dalam Universal Declaration of Human Rights pada Article 25 yang menyebutkan bahwa "everyone has the right to a standard of living adequate for the health and well being of himself and of his family including food, clothing, housing and medical care and necessary social services, and the right to security in the event of unemployment, sickness, disability, widowhood, old age or other lack of livelihood in circumstances beyond his control". Pernyataan ini ditindaklanjuti dengan International Covenant on Economic, Social and Culture Rights 1961 Article 12 yang menyatakan " the States Parties to the present covenant recognized the right of everyone to the enjoyment of the highest attainable standard of phisical and mental health".

Melalui amandemen ke 4 UUD 1945, sebagai salah satu bentuk untuk mewujudkan tujuan negara yakni memajukan kesejahteraan umum, maka hak asasi atas kesehatan, sebagai salah satu indikator nilai kesejahteraan manusia, diakui sebagai hak konstitusional di dalam Pasal $28 \mathrm{H}$ ayat (1) UUD 1945 yang menyebutkan bahwa "setiap orang berhak hidup sejahtera lahir dan batin,...serta berhak memperoleh pelayanan kesehatan". Pengakuan ini ditindaklanjuti dengan penetapan kewajiban negara untuk menyediakan fasilitas kesehatan yang dicantumkan di dalam Pasal 34 ayat (3) bahwa "negara bertanggungjawab atas penyediaan fasilitas pelayanan kesehaan dan fasilitas pelayanan umum yang layak." Kedua ketentuan di atas menjadi landasan 
konstitusional lahirnya berbagai peraturan perundang-undangan yang terkait pelayanan kesehatan kepada masyarakat, baik pelayanan kesehatan individual maupun masyarakat luas (kelompok)

Undang-Undang Nomor 36 Tahun 2009 tentang Kesehatan yang menggantikan UndangUndang Nomor 23 Tahun 1992 telah meletakkan fondasi baru atas pembangunan kesehatan yang didasarkan pada nilai-nilai hak asasi manusia atas pemenuhan kesehatan. Pasal 4 UU Nomor 36 Tahun 2009 menyebutkan bahwa "setiap orang berhak atas kesehatan", dan berdasarkan Penjelasan Pasal 4 dinyatakan bahwa "hak atas kesehatan yang dimaksud adalah hak untuk memperoleh pelayanan kesehatan dari fasilitas pelayanan kesehatan agar dapat mewujudkan derajat kesehatan yang setinggi-tingginya". Upaya mewujudkan derajat kesehatan tersebut harus diselenggarakan melalui pelayanan kesehatan yang bermutu, bertanggung jawab dan terjangkau bagi seluruh lapisan masyarakat, yang diberikan oleh para tenaga kesehatan yang profesional. Oleh karena itu keberadaan tenaga kesehatan yang profesional menjadi salah satu kebutuhan mendasar dalam pembangunan kualitas sumber daya manusia Indonesia.

Undang-Undang Kesehatan Pasal 21 ayat (3) mengamanatkan bahwa ketentuan tentang tenaga kesehatan harus diatur di dalam suatu undang-undang. Hingga tahun 2009, hanya profesi tenaga medis (dokter) saja yang telah memiliki payung hukum dalam bentuk undang-undang, sementara tenaga kesehatan lain baru diatur dalam peraturan perundang-undangan setingkat Peraturan Pemerintah (PP Nomor 32 Tahun 1996 tentang Tenaga Kesehatan) dan Peraturan Menteri Kesehatan (a.l. Permenkes Nomor 1464/MENKES/PER/X/2010 tentang ljin dan Penyelenggaraan Praktik Bidan, Permenkes Nomor H.K.02.02/MENKES/148/1/2010 tentang Ijin ddan Penyelenggaraan Praktik Perawat). Kondisi ini dianggap belum memberikan perlindungan dalam bentuk kepastian hukum yang tegas kepada para penyandang profesi tenaga kesehatan, sekaligus kepada masyarakat sebagai pengguna pelayanan kesehatan.

Salah satu tenaga kesehatan yang keberadaaannya dirasakan sangat vital di dalam sistem pelayanan kesehatan adalah tenaga keperawatan. Dalam UU Nomor 36 Tahun 2009 tentang Kesehatan disebutkan bahwa tenaga keperawatan yang merupakan bagian dari tenaga kesehatan harus memiliki kualifikasi minimum dan wewenang khusus yang sesuai dengan bidang keahlian masing-masing dalam menyelenggarakan pelayanan kesehatan. Setiap tenaga kesehatan, termasuk tenaga keperawatan berhak untuk mendapatkan perlindungan hukum sesuai dengan tugas profesinya. Pernyataan Pasal 27 UU Kesehatan tersebut secara tegas menuntut adanya sistem hukum yang akan memberikan perlindungan dan kepastian hukum kepada profesi tenaga kesehatan agar pelayanan yang diberikan pun menjadi suatu pelayanan yang bersifat dan berkarakteristik profesional.

Perawat, merupakan salah satu tenaga kesehatan yang secara kuantitas adalah terbesar di Indonesia, dan di dalam menjalankan tugas profesinya mempunyai frekuensi/ intensitas pertemuan yang lebih besar dengan pasien dibandingkan dengan tenaga kesehatan lainnya. Hal ini dapat dimungkinkan terjadi karena cakupan keperawatan itu sendiri yang demikian luas terhadap kesehatan seseorang, seperti yang dinyatakan oleh pelopor keperawatan modern Florence Nightingale bahwa, "nursing is having charge of the personal health of somebody... and what nursing has to do... is put the patient in the best possible condition for nature to act upon him.1. Demikian pula The International Council of Nursing (ICN) menyebutkan bahwa:

Nursing encompasses autonomous and collaborative care of individuals of all ages, families, groups and communities, sick or well and in all settings. Nursing includes the promotion of health, prevention of illness, and the care of ill, disabled and dying people. Advocacy,

1 Wheeler, Herman; 2012; Law, Ethics And Professional Issues For Nursing; Published by Routledge; New York, USA, p. 7 
promotion of a safe environment, research, participation in shaping health policy and in patient and health systems management, and education are also key nursing roles." ${ }^{2}$

Pernyataan-pernyataan tersebut memberikan gambaran di samping luasnya cakupan keperawatan dalam suatu pelayanan kesehatan kepada pasien/klien, juga menggambarkan pemahaman bahwa konsep keperawatan bersumber pada suatu tindakan yang bersifat caring (perawatan/pemeliharaan) dan bukan curing (pengobatan). Pemahaan konsep demikian kemudian diadopsi oleh berbagai negara maju dalam menyusun regulasi keperawatannya, seperti Amerika Serikat yang memiliki The Nurses Act di hampir setiap negara bagiannya, ataupun Singapura, sebagai negara ASEAN yang menempati urutan teratas dalam keberhasilan sistem pelayanan kesehatan modern. Keberadaan undang-undang (The act) di dalam pengaturan penyelenggaraan pelayanan keperawatan profesional ini bertujuan tidak saja memberikan kepastian dan perlindungan hukum kepada masyarakat, tetapi juga kepada perawat sebagai penyandang profesi keperawatan dalam menyelenggarakan pelayanan keperawatannya melalui penetapan standar pelayanan kesehatan dan standar pendidikan keperawatan dalam upaya mendukung profesionalitas keperawatan itu sendiri.

Seperti halnya kemajuan di bidang ilmu dan tekhnologi kesehatan lainnya, ilmu dan tekhnologi di bidang keperawatan pun mengalami perkembangan yang cukup pesat. Berbagai perkembangan dan kemajuan tersebut perlahan melahirkan paradigma baru yang berkaitan dengan kedudukan dan status profesi perawat dalam suatu sistem pelayanan kesehatan. Perawat menuntut untuk diberi kedudukan yang mandiri dalam keilmuannya dan tidak lagi bergantung pada perintah dokter. Perawat memiliki cakupan standar pelayanan yang disertai hak dan kewajiban untuk nantinya melahirkan tanggung jawab yang juga bersifat mandiri, dalam arti perawat harus bertanggung jawab atas segala tindakan yang dilakukannya dan bukan semata-mata tanggung gugat bersama tenaga kesehatan lainnya, khususnya dokter. Namun konsep paradigma baru ini tidak serta merta diterima oleh kalangan profesi kesehatan lainnya. Bahkan di negara-negara maju sekalipun, proses penerimaan paradigma baru, berupa paradigma kesetaraan ini membutuhkan waktu yang cukup panjang, yang pada akhirnya melahirkan berbagai peraturan perundang-undangan terkait praktik keperawatan profesional.

ICN sebagai organisasi profesi perawat internasional telah berupaya membangun konsep keperawatan profesional berlandaskan nilai dan asas kesetaraan yang kemudian diikuti oleh berbagai regulasi negara-negara anggota ICN. Hingga saat ini, di samping ketentuan dari ICN, sistem keperawatan profesional di negara Amerika, yang dikeluarkan oleh American Nurses Association (ANA), masih menjadi salah satu acuan bagi pengembangan berbagai produk hukum yang mengatur penyelenggaraan praktik keperawatan yang bertujuan memberikan kesetaraan bagi profesi perawat di atas landasan kemandirian ilmu keperawatan.

Nilai kesetaraan (equality) yang dikehendaki oleh profesi perawat pada prinsipnya berkaitan dengan kedudukan sebagai bagian dari tenaga kesehatan yang dilandasi oleh ilmu keperawatan. Cita-cita dan keinginan para penyandang profesi ini juga berimbas kepada sistem pelayanan kesehatan di Indonesia. Puncaknya adalah dengan diundangkannya UU Nomor 38 Tahun 2014 tentang Keperawatan.

UU Keperawatan 2014 yang dijiwai oleh nilai kesebandingan dan asas kesetaraan menghendaki kemandirian perawat dalam menjalankan profesi keperawatannya. Hal ini tercermin dari adanya asas etika dan profesionalitas yang tercantum sebagai salah satu asas hukum UU Keperawatan 2014. Namun konsep asas etika dan profesionalitas ini pun masih membutuhkan penjabaran yang lebih konkrit di dalam derivasi kaedah-kaedah yang berlaku.

${ }^{2}$ http://www.icn.ch/who-we-are/icn-definition-of-nursing; diunduh tanggal 23 Oktober 2015 
Keperawatan adalah suatu profesi. Hal ini dengan tegas dinyatakan di dalam UU Nomor 38 Tahun 2014 Pasal 1 angka 3 yang menyebutkan bahwa pelayanan keperawatan adalah suatu bentuk pelayanan kesehatan profesional yang merupakan bagian integral dari pelayanan kesehatan yang didasarkan pada ilmu dan kiat keperawatan, ditujukan kepada individu, keluarga, kelompok, atau masyarakat, baik sehat maupun sakit. Sebagai suatu pelayanan yang bersifat profesional dibutuhkan kaedah-kaedah hukum yang dilandasi asas-asas hukum yang mendukung profesionalitas tersebut, salah satunya adalah asas otonomi.

Asas otonomi selama ini dikenal sebagai asas yang berkorelasi dengan penghormatan hak-hak pasien yang harus dijaga dan ditaati oleh tenaga kesehatan, termasuk perawat. Namun sebagai suatu asas hukum yang bertujuan memberikan landasan filsafati kaedah-kaedah hukum yang mengatur tentang pelayanan profesional tersebut, asas otonomi tidak semata-mata diarahkan kepada kebebasan dan kemandirian pasien/klien sebagai penerima pelayanan kesehatan namun juga suatu asas yang melandasi kebebasan seorang perawat dalam menjalankan kewajiban profesionalnya.

Berdasarkan uraian di atas, maka permasalahan pokok yang akan dibahas di dalam tulisan ini adalah: bagaimanakah fungsi asas otonomi profesi terhadap pengembangan figur hukum keperawatan dalam sistem hukum kesehatan nasional.

\section{B. Fungsi Asas Hukum dalam Pembentukan Norma Hukum Keperawatan dalam Sistem Hukum Kesehatan}

Asas hukum merupakan suatu landasan yang paling luas bagi lahirnya suatu peraturan hukum, konsekuensinya bahwa setiap peraturan hukum harus dapat dikembalikan kepada asasasas tersebut. Asas hukum pun merupakan alasan bagi lahirnya suatu peraturan hukum atau yang disebut dengan ratio leges. Kedua hal inilah yang menjadikan alasan Prof. Satjipto Rahardjo menyebutkan keberadaan asas hukum sebagai jantungnya peraturan hukum ${ }^{3}$. Sementara menurut Paul Scholten, dalam Bruggink ${ }^{4}$ disebutkan bahwa asas hukum merupakan suatu pikiran-pikiran dasar yang terdapat di dalam dan di belakang sistem hukum masing-masing yang dirumuskan dalam aturan perundang-undangan dan putusan-putusan hakim yang berkenaan dengannya ketentuan-ketentuan dan keputusan-keputusan individual dapat dipandang sebagai penjabarannya.

Dalam kaitannya dengan kaedah perilaku, Bruggink menjelaskan bahwa asas hukum dipandang dapat memenuhi fungsi yang sama seperti kaedah perilaku karena asas hukum sebagai suatu meta kaedah memuat ukuran/kriteria nilai. Di sini asas hukum akan berfungsi untuk merealisasikan sebanyak mungkin ukuran nilai tersebut ke dalam kaedah-kaedah dari hukum positif dan penerapannya. Dengan demikian, asas hukum yang berisi ukuran nilai, akan berada di dalam maupun di belakang suatu sistem hukum positif. Dan sebagai suatu kaedah penilaian, asas hukum mewujudkan kaedah hukum tertinggi dari suatu sistem hukum positif. Agar asas hukum dapat menjalankan fungsinya sebagai pedoman bagi kaedah perilaku maka asas hukum harus dikonkretisasikan ke dalam sistem hukum positif melalui penetapan aturan-aturan hukum positif dan putusan-putusan pengadilan. Hal inilah yang pada akhirnya melahirkan fungsi asas hukum sebagai suatu batu-uji klinis terhadap sistem hukum positif.

Hukum keperawatan sebagai bagian dari sistem hukum kesehatan membutuhkan asas-asas hukum dalam membentuk kesatuan kaedah-kaedah perilaku sebagai suatu jalinan nilai yang ajeg. Asas hukum diperlukan dalam membentuk sistem hukum yang nantinya akan berfungsi untuk mewujudkan tujuan hukum seperti yang dinyatakan oleh Gustav Radbruch yakni memberikan

\footnotetext{
${ }^{3}$ Satjipto Rahardjo; 2006; Ilmu Hukum; PT Citra Aditya Bakti; Bandung; hlm. 45

${ }^{4}$ Bruggink, alih bahasa B. Arief Sidharta; 2011; Reflksi tentang Hukum, Pengertian-Pengertian Dasar dalam Teori Hukum; PT Citra Aditya Bakti; Bandung; hl. 120
} 
keadilan, kemanfaatan (finalitas) dan kepastian hukum ${ }^{5}$, melalui norma hukum yang mengaturnya. Sistem hukum yang dibangun, menurut Muchtar Kusumaatmadja, tidak sematamata mencakup asas-asas dan kaedah-kaedah hukum, tetapi juga mencakup lembaga-lembaga hukum dan proses untuk mewujudkan hukum tersebut dalam suatu kenyataan. Dengan demikian sistem hukum keperawatan yang akan dibangun haruslah berakar dari asas-asas dan kaedahkaedah hukum sebagai suatu jalinan nilai yang memiliki tujuan khusus yakni keadilan, kemanfaatan dan kepastian.

Keadilan, merupakan jiwa dan substansi pokok suatu hukum. Keadilan dalam sistem hukum keperawatan tidak saja terbatas pada makna definitif yang dinyatakan oleh UU Keperawatan sebagai suatu keadilan terhadap pelayanan kesehatan/keperawatan yang diberikan melainkan juga keadilan terhadap kedudukan dan tanggung jawab yang harus dihadapi setiap tenaga kesehatan/keperawatan atas seluruh tindakan asuhan yang diberikannya. Sementara kemanfaatan diarahkan kepada adanya manfaat yang diterima oleh tenaga keperawatan dalam upaya meningkatkan dan mengembangkan profesionalitas keilmuan yang dimilikinya, sementara kepastian hukum ditujukan kepada adanya perlindungan kepada setiap perawat yang menyelenggarakan pelayanan keperawatan dalam bentuk adanya kepastian terhadap batasan kewenangan, dan tanggung jawab yang dihadapi sehingga perawat akan memiliki rambu-rambu hukum dalam menyelenggarakan pelayanan keperawatan.

Hukum keperawatan merupakan sub-sistem dari hukum kesehatan, yang kemudian membentuk sistemnya sendiri yang terjalin dalam asas dan keadah-kaedah yang melandasi penyelenggaraan pelayanan keperawatan sebagai upaya pemenuhan kebutuhan pelayanan kesehatan masyarakat. Oleh karena itu asas-asas hukum yang melandasi dan membentuk sistem hukum keperawatan tidak boleh bertentangan dengan sistem hukum di atasnya yang lebih besar yakni sub-sistem hukum tenaga kesehatan, sub sistem hukum kesehatan dalam sistem hukum nasional itu sendiri. Asas-asas hukum itu sendiri nantinya harus merupakan derivasi dari nilai-nilai Pancasila, yakni Nilai ketuhanan, Nilai Kemanusiaan, Nilai Persatuan, Nilai Musyawarah mufakat dan nilai Keadilan Sosial, maupun nilai etik profesional keperawatan yakni Nilai kemanusiaan, nilai kebaikan, nilai kebenaran, nilai keadilan, dan nilai ilmiah. Keseluruhan nilai-nilai tersebut dapat dielaborasi dalam suatu susunan asas hukum dan keadah hukum yang menguatkan konsep pelayanan keperawatan sebagai suatu pelayanan altruistik ${ }^{6}$, yakni pelayanan yang mendahulukan kepentingan pihak lain (dalam hal ini adalah kepentingan pasien/klien) dibandingkan kepentingan diri sendiri/kelompok atau bahkan profesi.

\section{Fungsi Asas Otonomi Profesi Terhadap Pengembangan Figur Hukum Keperawatan Dalam Sistem Hukum Kesehatan Nasional}

Hukum keperawatan sebagai bagian dari sistem hukum kesehatan, tidak dapat mengandung asas-asas hukum yang bertentangan dengan asas-asas hukum di dalam sistem hukum kesehatan dan sistem hukum nasional, yang memiliki tujuan utama yakni untuk mendukung terlaksananya pembangunan kesehatan. Pembangunan kesehatan yang diselenggarakan melalui upaya kesehatan harus diselenggarakan oleh tenaga kesehatan profesional, yang mampu bersaing dalam penguasaan ilmu pengetahuan dan tekhnologi kesehatan semakin berkembang dengan pesatnya. Setiap tenaga kesehatan dituntut untuk mengembangkan dan menerapkan ilmu pengetahuan dan tekhnologi tersebut dalam

${ }^{5}$ Bernard L. Tanya et al; 2013; Teori Hukum, Strategi Tertib Manusia Lintas Ruang dan Generasi; Genta Publishing; Yogyakarta; hlm. 117

${ }^{6}$ Konsep altruistik dimaknai sebagai intentional and voluntary act performed to benefit another person as the primary motivation and either without a conscious expectation; Svetlana Feign, Glynn Owens \& Felicity Goodyears-Smith; Review of Theories of Human Altruism : a systematic Review; Annals of Neuroscience and Psychology Journal (ANP); ISSN 2058-7805; October,2015; Aucland New Zealand; diunduh dari www.vipoa.org/neoropsychol 
penyelenggaraan pelayanan yang diberikan kepada masyrakat secara bermutu, akuntabel, dan bertanggung jawab. Namun sebagai suatu bentuk pelayanan yang memiliki karakteristik khas, yakni suatu pelayanan altruistik maka hukum keperawatan tidak dapat mengesampingkan kepentingan pasien/klien untuk suatu kemajuan ilmu pengetahuan. Pemanfaatan dan penerapan ilmu dan tekhnologi kesehatan harus mampu memenuhi kebutuhan kesehatan masyarakat.

Di sisi lain, seorang tenaga kesehatan profesional, termasuk perawat, harus memahami konsep-konsep dan penerapan wewenang profesi yang dimilikinya agar tidak terjadi tumpang tindah kewenangan dalam menjalankan kewajiban profesionalnya. Untuk itu, setiap tenaga kesehatan wajib memiliki kemandirian yang kuat sehingga mampu mengimplementasikan ilmu dan tekhnologi kesehatan yang dikuasainya tersebut untuk memebrikan pelayanan yang sesuai kebutuhan pasien/klien dan tetap dalam batas-batas wewenang profesi maupun wewenang hukum yang melekat pada profesinya.

Asas-asas hukum yang tercantum di dalam UU Kesehatan, UU Keperawatan dan UU Tenaga Kesehatan harus mengandung nilai-nilai etis yang berfungai untuk menjembatani peraturan-peraturan hukum dengan cita-cita sosial yakni kesejahteraan umum masyarakat melalui pencapaian derajat kesehatan yang setingggi-tingginya, dan pandangan etis masyarakat yakni terpenuhinya nilai-nilai yang menghargai dan menghormati harkat dan martabat kemanusiaan di dalam penyelenggaraan pelayanan kesehatan. Oleh karena itu asas-asas hukum yang melandasi peraturan-peraturan hukum di bidang pelayanan keperawatan haruslah mencerminkan nilai-nilai etis kemanusiaan tersebut.

Nilai etis yang mendasari asas-asas hukum tersebut bukan saja sekedar memberikan perlindungan terhadap harkat dan martabat pasien/klien tetapi juga terhadap perawat itu sendiri selaku tenaga kesehatan agar pelayanan yang diberikan tetap berada dalam suatu sistem hukum yang berkarateristik humanis profesional seperti yang dicntumkan di dalam konsiderans UU Keperawatan itu sendiri. Perlindungan dan kepastian hukum tersebut diperlukan profesi perawat untuk memberikan kedudukan yang setara dengan tenaga kesehatan lain khususnya tenaga medis (dokter) sehingga dapat dilakukan maksimalisasi pelayanan keperawatan. Oleh karena itu diperlukan asas-asas hukum yang memuat nilai-nilai kemanusiaan dan keadilan sekaligus prinsip etik profesi kesehatan yakni respect to the person/autonomy, beneficence,nonmalaficence, dan justice ${ }^{7}$. Keempat prinsip etik profesi -lebih tepat disebut sebagai nilai etis- tersebut harus menjadi landasan filosofis keberadaan asas-asas hukum yang akan diwujudkan dalam kaedah hukum /kaedah perilaku yang konkret.

UU Keperawatan (dan UU Tenaga Kesehatan) mencantumkant asas etik dan profesionalitas yang memberikan arah kepada profesi perawat untuk menyelenggarakan pelayanan keperawatan berdasarkan dan berlandaskan pada nilai-nilai etik profesi. Namun keberadaan asas hukum ini pun dirasakan masih belum memadai untuk menempatkan perawat dalam kedudukan yang setara melalui beban tanggung jawab yang sebanding dengan kewenangan yang dimiliki, terhadap tenaga kesehatan lainnya. Dengan demikian, dibutuhkan asas-asas hukum lain yang mampu melahirkan peraturan-peraturan hukum yang lebih konkrit di dalam memberikan kesetaraan kedudukan dan kesebandingan tanggung jawab tersebut. Asas hukum yang dimaksud adalah asas otonomi yang nantinya harus diimbangi dengan asas akuntabilitas profesi. Keduanya akan saling melengkapi tanpa menyingkirkan/mengesampingkan tujuan implementasi asas-asas hukum yang lain, termasuk asas-asas hukum yang tercantum di dalam Pasal 6 UU Nomor 12 Tahun 2011 serta keempat prinsip etik kesehatan, dimana keseluruhan asas-asas hukum tersebut pada akhirnya akan berorientasi pada tujuan menciptakan perlindungan dan keselamatan pasien/klien.

7 Dikutip dari Bishop, Laura; Ethics Background, Principles; Kennedy Institute of Ethics, Georgetown University; USA; diunduh dari https://www.nwabr.org tanggal 12 februari 2016 , pkl 03.15 WIB 
Prinsip otonomi selama ini dikenal sebagai suatu prinsip/nilai yang terkait erat dengan hakhak pasien/klien dalam suatu pengambilan keputusan terhadap tindakan kesehatan yang akan diberikan oleh tenaga kesehatan. Kata otonomi berasal dari bahasa Yunani autos (diri sendiri) dan nomos (aturan) ${ }^{8}$, sehingga apabila diartikan secara harfiah kata otonomi mempunyai makna sebagai peraturan dari diri sendiri. Di bidang kesehatan/kedokteran, otonomi merupakan salah satu fondasi utama perlindungan dan penghormatan terhadap harkat dan martabat kemanusiaan. Oleh karena itu berbagai kamus kedokteran/kesehatan memberikan pemaknaan terhadap kata otonomi sebagai sesuatu kepentingan yang merujuk pada kebebasan berkehendak dari para pihak yang terlibat di dalam suatu hubungan terapeutik.

Makna /definisi otonomi /autonomy dikutip dari beberapa kamus kedokteran (dictionary of medicine) antara lain :

1. Encyclopedia and Dictionary of Medicine, Nursing and Allied Health memberikan makna autonomy is the ability to function in an independent fashion and in bioethics: autonomy as self determination that is free from both controling interferences by others and personal limitations preventing meaningful. ${ }^{9}$

2.McGraw-Hill memberikan definisi autonomy dalam konteks vox populi yakni personal capacity to consider alternatives, make choices and act without under influence or interference from others. ${ }^{10}$

3. Jonas: Mosby's Dictionary of Complementary and Alternatives Medicine : autonomy is a principle of medical ethics according to which a person should respect the rights of other iindividuals to freely determine their own choices and decisions. ${ }^{11}$

Dari beberapa pengertian di atas dapat diambil kesimpulan bahwa pada prinsipnya makna otonomi adalah suatu kebebasan yang dimiliki seorang individu dalam menentukan tindakan yang akan dilakukannya, tidak saja hanya terbatas pada pasien/klien tetapi juga dimiliki seorang pekerja profesional. Konsep inilah yang kemudian membuat The American Nurses Association (ANA) memberikan definisi nya terhadap kata autonomy sebagai "agreement to respect another's right to self determine a course of action, support of independent decision making"'12. Definisi ini tidak saja semata-mata memberikan hak kepada pasien/klien dalam hal menetapkan suatu keputusan terkait tindakan (treatment) tertentu di bidang kesehatan/keperawatan, tetapi juga mencakup hak yang dimiliki perawat dalam mengambil keputusan yang tentunya terkait dengan tindakan keperawatan kepada pasien/klien. Konsep yaang diberikan ANA ini telah menyiratkan pengakuan terhadap hak otonomi profesi yang dimiliki seorang perawat dalam menjalankan kewajibannya.

Otonomi selalu berkaitan erat dengan hak diri sendiri dalam mengambil suatu keputusan yangg dianggap terbaik atas dasar pengetahuan dan pemahaman diri yang bersangkutan. Berkaitan dengan makna tersebut, Immanuel Kant ${ }^{13}$ menyebutkan bahwa otonomi merupakan

\footnotetext{
${ }^{8}$ Van Norman, Gail; Informed Consent: Respecting Patient Autonomy; CSA Bulletin; p. 36-46 diunduh dari www.csahq.org/pdf/.../informed_consent tanggal 12 Februari 2016 : pkl. 03.34 WIB

${ }^{9}$ Miller-Keane; 2003; Encyclopedia and Dictionary of Medicine, Nursing and Allied Health, 7th edition; diunduh dari http://medical-dictionary.thefreedictionary.com; tanggal 12 Februari 2016 , pkl 03.15 WIB

${ }^{10}$ ibid

11 ibid

12 Short Definitions of Ethical Principles and Theories; American Nurses Association; diunduh dari www.nursingworld.org/.../Ethics-Definitions.pdf tanggal 12 februari 2016 , pkl 03.15 WIB

${ }^{13}$ Kant: The Moral Order diunduh dari http://www.philosohypages.com/hy/5i.htm; periksa juga von Platz, Jeppe; Autonomy as the Supreme Prinicple of Morality; users.wfu.edu/hardgra/kanteth.html diunduh tanggal 12 februari 2016, pkl 03.15 WIB
} 
suatu hak moral yang paling mendasar yang dimiliki setiap manusia.Menurut Kant "autonomy is the ground of the dignity of human nature and of every rational nature", oleh karena itu "autonomy of the will is the supreme principle of morality; the sole principles of morals"14. Sebagai suatu prinsip moral yang paling mendasar, hak otonomi seyogyanyalah dimiliki oleh semua manusia, karena otonomi berkaitan dengan kebebasan berkehendak dan menentukan pilihan terhadap dirinya sendiri diatas kesadaran yang dimilikinya secara penuh.

Konsep prinsip otonomi dalam teori Kant di atas telah diterapkan dalam semua aspek hukum, termasuk di bidang kesehatan sebagai suatu prinsip pendukung etik profesi. Makna otonomi (autonomy) sebagai prinsip etis (atau dalam tatanan ilmu hukum, lebih tepat disebut dengan isilah nilai etis) merupakan bentuk lain dari prinsip respect for the human/person di dalam bidang kesehatan. Dengan demikian, otonomi itu sendiri harus mengandung nilai-nilai yang menjunjung harkat dan martabat manusia sebagai mahkluk yang bebas, tanpa terkecuali, termasuk harkat dan martabat kemanusiaan penyandang profesi itu sendiri. Kebebasan yang dimiliki setiap orang dalam menyampaikan kehendak terhadap tindakan yang dilakukannya yang menurut penilaiannya adalah terbaik untuk dirinya dan orang lain yang menjadi bagian dari tanggung jawab moralnya. Oleh karena itu, di dalam kesehatan, otonomi seyogyanya tidak saja semata-mata sebagai suatu hak yang dimiliki oleh pasien/klien tetapi juga merupakan hak yang dimiliki para tenaga kesehatan dalam menentukan apa yang terbaik berdasarkan ilmu pengetahuan dan kompetensinya. Konsep otonomi yang demikian inilah yang menurut penulis disebut dengan asas otonomi profesi.

Sebagai salah satu asas hukum keperawatan, asas otonomi profesi (perawat) akan merujuk pada makna kebebasan bertindak yang dimiliki perawat selaku tenaga kesehatan profesional di bidang pelayanan kesehatan / keperawatan, dalam hal mengambil keputusan sesuai dengan rencana dan upaya yang ditentukannya sendiri berdasarkan keahlian, ketrampilan, dan ketelitian yang dimilikinya kepada klien/pasien yang membutuhkan. Asas otonomi profesi sebagai suatu asas yang memberikan arah pada lahirnya kaedah perilaku, seperti yang dinyatakan oleh Bruggink, akan memberikan kedudukan yang setara kepada perawat dalam suatu sistem pelayanan kesehatan, melalui pemberian hak $^{15}$ dan kewajiban serta kewenangan profesi yang disandangnya.

Asas otonomi ini nantinya akan melahirkan berbagai kaedah hukum yang mengatur kewenangan dan hak-hak perawat dalam menjalankan tugas dan kewajiban keperawatannya tanpa adanya tekanan maupun paksaan (interfere) dari pihak manapun. Oleh karena itu asas otonomi harus diimbangi dengan keberadaan asas akuntabilitas profesi agar tujuan hukum yakni keadilan dapat tetap terwujud.

Sebagai suatu asas hukum yang mengandung nilai-nilai etis dalam upaya mewujudkan harapan dan cita-cita masyarakat pendukungnya, maka asas hukum otonomi profesi di dalam sistem hukum keperawatan disamping mengandung nilai respect for person, juga harus mengandung nilai nonmaleficence (tidak menyakiti), beneficence (berbuat baik) sekaligus merefleksikan nilai justice (keadilan). Hal ini dilakukan karena asas otonomi tidak saja mendukung terlaksananya hubungan perawat-klien yang bersifat mutual obligation dan altruistsm, tetapi asas otonomi ini juga diperlukan sebagai upaya menghormati dan menghargai kapasitas dan profesionalitas perawat dalam menjalankan tugas dan kewajibannya yang dilandasi nilai moral

${ }^{14}$ Ibid; hlm, 12

${ }^{15}$ Hak di sini diartikan sebagai suatu kepentingan yang dilindungi oleh hukum, berdasarkan pada pendapat Jhering, dimana di dalamnya mengandung sesuatu kekuasaan untuk bertindak dalam rangka kepentingan tersebut seperti yang dinyatakan oleh Pound, dan hak ini diakui dan dilindungi oleh hukum positif menurut pendapat Paton. 
dan etik yang diyakininya sebagai seorang manusia ${ }^{16}$, meskipun dalam kenyataan praktik seharihari adalah sulit untuk memisahkan antara etik individual dan etik profesional. Oleh karena itu otonomi sebagai suatu hak moral yang dimiliki pasien/klien harus diimbangi dengan penghargaan terhadap otonomi profesi perawat dalam kedudukannya yang setara dengan tenaga kesehatan lain khususnya tenaga medis (dokter) berupa pembatasan wewenang dan tanggung jawab, serta adanya pengaturan yang lebih baik dalam menyikapi fungsi perawat yang demikian majemuk.

Pada dasarnya landasan nilai moral terhadap otonomi profesi tersebut bersumber pada hal yang sama seperti halnya dengan otonomi yang dimiliki pasien/klien. Oleh karena itu penerapan/penggunaan hak otonomi seorang profesional kesehatan (baik dokter maupun perawat) tidak dapat dilepaskan dari nilai-nilai individual yang diyakni pelaku profesional itu sendiri seperti nilai -nilai keagamaan, sosial dan budaya serta keyakinan-keyakinan individual lainnya yang tentunya akan berbeda dengan orang lain namun berpengaruh kuat terhadap keputusan atas pertimbangan dan tindakan yang diberikan kepada pasien/klien. Dengan demikian, hak otonomi pasien/klien tidak boleh mengorbankan nilai-nilai moral yang disandang profesi dokter/perawat meskipun menurut pandangan pasien/klien apa yang diputuskannya adalah yang terbaik untuk dirinya sendiri.

Asas otonomi memberikan perlindungan terhadap kebebasan berkehendak yang dimiliki perawat dalam menentukan tindakan yang akan dilakukannya demi keselamatan dan kesehatan klien/pasien dengan berlandaskan pada pemahaman, pengetahuan dan ketrampilan keperawatan yang dimilikinya. Kebebasan berkehendak dalam hal ini terkait pada pilihannya dalam menentukan tindakan yang dirasakannya paling tepat bagi kesehatan pasien, karena masalah tersebut tidaklah semata-mata berkisar pada ketrampilan dan pengetahuan belaka, tetapi juga mengandung unsur "art", dalam arti bahwa seorang perawat dalam menentukan suatu tindakan harus memperhatikan kondisi bio-fisik- psiko sosial pasien/klien yang bersangkutan. Hal ini sejalan dengan salah satu nilai filsafati dalam keperawatan yakni aesthetics (keindahan) ${ }^{17}$. Nilai aesthetics memberikan makna adanya suatu keindahan yang berhubungan dengan kualitas obyek suatu peristiwa atau kejadian, dalam hal ini berarti perawat berkewajiban memberikan kepuasan pelayanan termasuk penghargaan, kreatifitas, imajinasi, sensitivitas, dan kepedulian terhadap pasien/klien. Dengan demikian, asas otonomi profesi yanag disandang perawat pun telah mencerminkan nilai beneficence (menguntungkan) dan nilai nonmalaficence (tidak menyakiti) karena segala keputusan yang diambil perawat tersebut bertujuan memberikan perawatan yang terbaik bagi pasien dengan menghindari tindakan-tindakan yang justru akan semakin menyakiti diri pasien, meskipun dalam praktik keseharian, hal tersebut tidak jarang sulit diterapkan karena adanya benturan konsep yang terbaik bagi pasien dan terbaik bagi perawat atas dasar penilaian keilmuan keperawatannya. Oleh karena itu, panduan nilai etis dan moral dalam bentuk kode etik profesi perlu dipegang teguh perawat agar segala keputusan yang diambil atas dasar otonomi profesi tetap berlandaskan pada penilaian etis dan moral profesi itu sendiri.

Asas otonomi profesi ini pun harus mencerminkan nilai keadilan (justice), dalam arti sebagai suatu keadilan distributif/proporsional yakni memberikan apa-apa yang menjadi haknya ${ }^{18}$. Perawat dalam menjalankan tugas dan kewajiban profesinya memiliki hak yang sebanding

\footnotetext{
${ }^{16}$ Pellegrini, Edmund.D; Patient aand Physician Autonomy: Conflicting Rights and Obligations in the Physician -Patient Relationships; Journal of Contemporary Health Law and Policy vol. 10:47 p. 47-68 , diunduh dari scholarship.law.edu/ tanggal 12 Februari 2016 pkl. 03.30 WIB

17 Nisya Rifiani \& Hartanti Sulihandari; 2013; Prinsip-Prinsip Dasar Keperawatan; Penerbit dunia Cerdas; Jakarta; hlm. 9-10

${ }^{18}$ Pengertian ini didasarkan pada konsep keadilan dari Aristoteles yang membagi konsep keadilan menjadi keadilan distributif dan keadilan komunitatif. Keadilan distributif juga identik dengan penyebutan keadilan proporsional melahirkan prinsip “memberi tiap orang apa yang menjadi haknya”, sementara keadilan komutatif melahirkan prinsip "semua orang sama di depan hukum”.Periksa Bernard L. Tanya et all;2013; Teori Hukum, Strategi Tertib Manusia Lintas Ruang dan Waktu; Penerbit Genta Publishing; Yogyakarta; hlm. 42.
} 
dengan tenaga kesehatan lain, atau dengan perkataan lain bahwa perawat berhak mendapatkan perlakuan yang adil dalam hubungannya dengan tenaga kesehatan lain, khususnya dokter, dalam menjalankan tugas dan kewajiban yang didasarkan pada ilmu keperawatan profesional, sehingga perawat berhak untuk mendapat perlindungan atas tindakan yang dilakukannya atas dasar kebebasan bertindak, sepanjang tindakan tersebut sesuai dengan kewenangan keilmuannya. Justice (keadilan) sebagai salah satu nilai filosofi keperawatan bertujuan mewujudkan nilai equality (kesetaraan) dalam menjalankan fungsi pelayanan kesehatan kepada masyarakat. Sehingga makna asas keadilan yang dicantumkan di dalam UU Kesehatan , UU Keperawatan serta UU Tenaga Kesehatan yang secara umum mencerminkan adanya pemerataan terhadap pelayanan kesehatan yang diberikan kepada masyarakat dengan meletakkan prinsip nondiskriminasi, kini dapat dikembangkan sebagai refleksi keadilan dalam memberikan perlindungan dan kepastian hukum yang sama (setara/equal) kepada tenaga keperawatan dalam menjalankan tugas dan kewajiban profesinya. Keadilan untuk memberikan hak dan kesempatan yang sama di dalam mengembangkan keilmuan keperawatan yang dimiliki dengan berlandaskan nilai kemanusiaan itu sendiri.

\section{Relevansi Asas Otonomi Profesi dan Asas Akuntabilitas dalam Mewujudkan Konsep Keadilan Profetik}

Asas otonomi profesi yang dilandasi oleh nilai kesetaraandan nilai kesebandingan hukum membutuhkan asas keterbukaan dalam tanggung jawab hukum, yang disebut dengan asas akuntabilitas (accountability principles) sebagai asas hukum yang bertujuan mengimbangi kebebasan berkehendak (free willing) yang melandasi keberlakuan asas otonomi. Di dalam Black's Law Dictionary, akuntabilitas (accountability) diartikan sebagai responsible, answerable ${ }^{19}$.

Penjelasan Umum UU Nomor 38 Tahun 2014 telah menyebutkan bahwa pelayanan keperawatan harus dilakukan secara bertanggungjawab, akuntabel, bermutu, dan aman. Tanpa menjelaskan apa yang dimaksud dengan akuntabel tersebut, UU Nomor 38 Tahun 2014 memberikan peluang untuk dilakukannya berbagai interpretasi terhadap makna akuntabel yang tercantum di dalam Penjelasan Umum tersebut. Salah satu interpretasi yang dilakukan adalah dengan melakukan interpretasi teleologis dan sistematis terhadap undang-undang lain yang berkorelasi dengan UU Nomor 38 Tahun 2014 yakni UU Kesehatan 2009, UU Rumah Sakit 2009, UU Tenaga Kesehatan 2014 hingga UU Nomor 25 Tahun 2009 tentang Pelayanan Publik. Dari berbagai undang-undang ersebut diperoleh gambaran akan makna dari akuntabel yang dikehendaki oleh UU Nomor 38 Tahun 2014. Akuntabel atau asas akuntabilitas dapat dimaknai sebagai suatu bentuk tanggung jawab terhadap seluruh tindakan yang dilakukan seorang tenaga perawat, yang didasarkan pada standar profesi dan standar pelayanan profesi keperawatan, yang dilakukan secara transparan dan obyektif. Seorang perawat harus mampu menjelaskan seluruh alasan logis seluruh tindakan dan asuhan keperawatan yang diberikan kepada pasien, dengan berorientasi pada asas perlindungan pasien.

Akuntabilitas mengandung makna adanya kemampuan dan kewajiban untuk mempertanggungjawabkan segala tindakan yang dilakukan kepada obyek tertentu yang berkepentingan atas tindakan tersebut. Dalam sistem hukum pelayanan keperawatan asas akuntabilitas merujuk pada makna adanya tanggung jawab dan tanggung gugat seorang perawat atas segala tindakan yang dilakukan maupun yang tidak dilakukan sehubungan dengan tugas profesinya di dalam suatu penyelenggaraan pelayanan keperawatan kepada masyarakat/klien/pasien. Asas akuntabilitas diperlukan untuk mengevaluasi kinerja dan sistem pelayanan keperawatan yang diberikan kepada klien/pasien oleh karena itu untuk menerapkan asas akuntabilitas diperlukan kaedah-kaedah hukum yang mendukung penyelenggaraan

${ }^{19}$ Garner, Bryan; Black’s Law Dictionary; 1990; 9th edition; WEST Publishing Co; USA; p.21 
pelayanan keperawatan secara transparan dan jelas sehingga tidak menimbulkan bias/multi tafsir dalam mengimplementasikan ketentuan-ketentuan yuridis tersebut.

Asas akuntabilitas harus selalu diterapkan secara abersamaan dengan asas otonomi profesi, dengan tujuan untuk membatasi kebebasan perawat dalam melakukan tindakan dan asuhan keperawatan kepada pasien, yang sesuai dengan wewenang profesi yang dimilikinya. Kebebasan yang diberikan oleh asas otonomi, harus diimbangi dan dibatasi oleh asas akuntabilitas sehingga pasien/klien dapat terlindungi secara keilmuan sekaligus secara hukum.

Salah satu mekanisme kinerja pelayanan keperawatan yang harus secara tegas diatur adalah standar pelayanan keperawatan serta standar profesi yang didasarkan pada kode etik profesi perawat karena makna tanggung jawab itu sendiri tidak terbatas pada tanggung jawab secara hukum tetapi juga tanggung jawab etis dan moral kepada organisasi profesi. Pada umumnya asas akuntabilitas sering dikaitkan dengan asas responsibilitas (responsibilities principle). Kedua asas ini saling berhubungan dan mengisi, dalam arti apabila asas responsibilitas (resnponsibility principle) mensyaratkan adanya bentuk hukum yang tegas terhadap terjadinya pelanggaran-pelanggaran yang dilakukan oleh profesi (perawat) yang menimbulkan suatu kerugian kepada klien/pasien, sementara asas akuntabilitas (accountability principle) lebih kepada pemaknaan akan adanya tanggung jawab utuh dari perawat untuk mampu menjelaskan setiap alasan dari tindakan yang dilakukan yang dianggap tidak sesuai dengan standar pelayanan keperawatan, standar profesi, maupun standar operasional prosedur walaupun tidak terdapat gugatan/tuntutan hukum dari klien/pasien, sehingga asas akuntabilitas lebih diperlukan dalam mengevaluasi kinerja dan sistem kinerja dari perawat dalam menerapkan keilmuannya, sementara asas responsibilitas lebih ditujukan kepada tanggung jawab hukum. Hal inilah yang menyebabkan asas akuntabilitas mempunyai unsur nilai profesional yang lebih kuat dibandingkan asas responsibilitas. Dengan demikian, apabila asas akuntabilitas menghendaki adanya tanggung jawab perawat atas segala tindakannya maka bentuk pertanggung jawaban hukum perawat tersebut lahir dari asas responsibilitas.

Asas responsibilitas diperlukan untuk memberikan jaminan terhadap adanya perlindungan hukum bagi masyarakat terhadap pelaksanaan pelayanan keperawatan, sementara asas akuntabilitas bertujuan memberikan kepastian hukum kepada penyandang profesi perawat dalam mengevaluasi kinerja kerja keperawatannya dalam upaya menciptakan pelayanan keperawatan yang profesional dan humanistis dengan berkeadilan.

Pengejewantahan asas akuntabilitas dalam bentuk kaedah-kaedah hukum, seperti juga asas otonomi, membutuhkan beberapa persyaratan yang harus terpenuhi yakni adanya penetapan standar profesi keperawatan dan standar pelayanan keperawatan yang jelas sebagai suatu patokan/tolok ukur dari tindakan yang seharusnya dilakukan/tidak dilakukan oleh perawat. Di atas telah disebutkan bahwa fungsi utama keberadaan asas akuntabilitas ini adalah untuk mengevaluasi kinerja kerja perawat dalam menjalankan kewajiban asuhan keperawatannya secara bertanggung jawab dan otonom, untuk itu diperlukan suatu lembaga yang berwenanga untuk melakukan segala bentuk pengawasan terhadap kinerja perawat, sampai dengan memberikan/menjatuhkan sanksi disiplin terhadap perawat yang melanggar standar profesi dan standar pelayanan keperawatan yang telah ditetapkan, dengan memberikan akses informasi terhadap masyarakat atas hasil pegawasan dan penegakan disiplin perawat tersebut. Seperti halnya yang diterapkan di negara-negara maju, seperti Amerika Serikat dengan The American Nursing Association (ANA), di Inggris dengan The Royal College of Nursing (RCN) yang mempunyai kewenangan penuh untuk melakukan mekanisme penegakan hukum dan disiplin terhadap penyelenggaraan pelayanan keperawatan, sehingga diharapkan pelayanan keperawatan benarbenar dapat terselenggara secara profesional. 
Keterlibatan organisasi profesi secara otonom dan tanpa keterlibatan pemerintah secara langsung tersebut telah memberikan gambaran bagaimana konsep otonomi profesi dikembangkan secara maksimal dalam membangun figur hukum perawat berbasis kesetaraan dalam sistem hukum keperawatan mereka.

Konsep yang sama atas eksistensi dan fungsi asas otonomi dan asas akuntabilitas profesi di dalam pengembangan figur hukum keperawatan dalam upaya menwujudkan perawat sebagai tenaga kesehatan profesional t juga diperlukan di dalam sistem hukum kesehatan nasional sebagai bagian dari upaya memenuhi kebutuhan pelayanan kesehatan bagi segenap warga negara sebagai hak asasi konstitusional yang telah diatur dan diakui di dalam Pasal $28 \mathrm{H}$ ayat (1) UUD RI 1945. Asas otonomi dan asas akuntabilitas profesi sebagai bagian dari sistem hukum yang terbentuk dari nilai-nilai etis yang berkembang di dalam dunia kesehatan akan membantu mengembangkan kinerja keperawatan yang lebih profesional dan humanistis berdasarkan nilainilai Pancasila dengan tujuan akhir mewujudkan kesejahteraan bagi seluruh rakyat Indonesia melalui pencapaian derajat kesehatan yang setinggi-tingginya.

\section{E. Refleksi dan Eksistensi Asas Otonomi Dalam Membangun Figur Hukum Keperawatan Sebagai Upaya Mewujudkan Perawat Sebagai Tenaga Kesehatan Profesional di Dalam Undang-Undang Nomor 38 Tahun 2014 tentang Keperawatan}

Asas otonomi dan asas akuntabilitas profesi dibutuhkan bagi pengembangan dan pembangunan figur hukum perawat sebagai tenaga kesehatan berbasis kesetaraan dan kesebandingan dalam sistem pelayanan kesehatan dan sistem (tata) hukum kesehatan nasional sebagai upaya menyediakan pelayanan kesehatan yang profesional kepada masyarakat. Sebagai bagian dari sistem hukum yang memuat nilai-nilai etis di bidang kesehatan serta keinginan dan cita-cita bangsa Indonesia dalam mewujudkan kesejahteraan masyarakat melalui pancapaian derajat kesehatan yang setinggi-tingginya , maka asas otonomi dan akuntabilitas profesi perlu diwujudkan dalam suatu susunan kaedah-kaedah hukum yang menjadi pedoman perilaku dan bertindak bagi penyandang profesi perawat sebagai bagian dari tenaga kesehatan.

Apabila dikaji dari substansi perundang-undangan yang mengatur penyelenggaraan pelayanan keperawatan, kedua asas hukum tersebut telah tercermin di dalam beberapa ketentuan UU Kesehatan, UU Keperawatan maupun UU Tenaga Kesehatan meskipun belum sepenuhnya direalisasikan dalam bentuk yang konkrit dan jelas.

Asas otonomi profesi yang pada prinsipnya bermakna bahwa penyandang profesi perawat memiliki kebebasan dalam menentukan pilihan terhadap berbagai tindakan yang akan diberikan kepada pasien/klien dengan didasarkan pada pertimbangan keilmuan keperawatan dan kondisi kesehatan pasien, tercermin dalam beberapa pasal di dalam UU Keperawatan diantaranya yang mengatur tentang hak-hak perawat yang tertuang di dalam Pasal 36 yang menyebutkan bahwa perawat dalam melaksanakan praktik keperawatan berhak :

1. Memperoleh perlindungan hukum sepanjang melaksanakan tugas sesuai dengan standar pelayanan, standar profesi, standar prosedur operasional, dan ketentuan peraturan perundang-undangan;

2. Memperoleh informasi yang benar,jelas dan jujur dari klien dan/atau keluarganya;

3. Menerima imbalan jasas atas pelayanan keperawatan yang diberikan;

4. Menolak keinginan klien atau pihak lain yang bertentangan dengan kode etik, standar pelayanan,standar profesi, standar prosedur operasional, atau ketentuan peraturan perundang-undangan; dan

5. Memperoleh fasilitas kerja sesuai dengan standar. 
Hak-hak yang diperoleh perawat dalam menjalankan tugas profesinya tersebut di atas belum sepenuhnya menyiratkan kesetaraan kedudukan dalam sistem pelayanan kesehatan, khususnya apabila di dalam suatu sistem kesehatan yang bersifat kolaboratif. Dalam arti perumusan hak-hak perawat tersebut di atas baru mencerminkan kedudukan perawat dalam hubungan profesionalnya dengan pasien/klien serta kedudukannya sebagai salah satu organ pemerintah yang melaksanakan kewajiban negara dalam menyelenggarakan pelayanan kesehatan, tetapi belum merupakan cerminan kesetaraan perawat dalam hubungannya dengan tenaga kesehatan lainnya khususnya dokter.

Konsep kesetaraan (equality) tidaklah untuk dimaknai sebagai persamaan dalam tugas dan tanggung jawab antara perawat dan tenaga kesehatan lain khususnya dokter, namun kesetaraan dalam hal ini dimakna sebagai suatu kedudukan yang setara (equal) dalam menyelenggarakan pelayanan kesehatan sesuai dengan bidang keilmuan dan ketrampilan masing-masing profesi, dimana perawat merupakan tenaga kesehatan yang mandiri dan bukan semata-mata perpanjangan tangan dokter (verlengede arm van de arts) atau hanya sekedar menjalankan perintah dokter semata-mata. Dalam batas kewenangan asuhan keperawatan, seorang perawat berkewajiban menjalankan tugas -tugas keperawatan yang melahirkan hak-hak perawat secara mandiri. Tugas dan kewajiban tersebut berkaitan erat dengan tanggung jawab yang harus dipikul perawat sebagai seorang individu. Beban tanggung jawab yang didasarkan pada kewajiban profesi inilah yang didasarkan pada nilai kesebandingan. Sehingga kesetaraan dan kesebandingan yang dikehendaki dalam figur seorang perawat adalah mencakup kedudukan perawat yang setara terhadap tenaga kesehatan lain dalam bentuk kewenangan dan tanggung jawab yang sebanding dengan ilmu keperawatan di dalam suatu sistem pelayanan kesehatan.

Keterkaitan asas otonomi profesi dalam keberadaan hak perawat sebagai upaya memberikan kedudukan yang setara dalam suatu sistem pelayanan kesehatan salah satunya adalah adanya hak (untuk) menolak. Di dalam Pasal 36 UU Keperawatan di atas disebutkan adanya hak perawat untuk menolak melakukan tindakan yang bertentangan dengan kode etik, standar pelayanan, standar profesi, standar prosedur operasional, atau ketentuan peraturan perundang-undangan lainnya, namun hak menolak tersebut hanya berkenaan dengan tindakan langsung kepada pasien/klien dan bukan dalam hubungannya dengan tenaga kesehatan lain khususnya dokter maupun perawat lain. Hak menolak yang dimiliki perawat terkait dengan tugas yang diberikan tenaga kesehaan lain, merupakan implementasi asas otonomi profesi yang dimiliki seorang perawat. Dengan demikian, pada pelaksanaannya hak menolak ini akan memiliki keterkaitan yang erat dengan mekanisme pelimpahan tugas/kewenangan yang dimiliki tenaga kesehatan lain kepada seorang perawat, yang berdampak pada tanggung jawab hukum yang lahir dari pelimpahan tersebut.

UU Tenaga Kesehatan dan UU Keperawatan mengatur masalah pelimpahan kewenangan di dalam Pasal 29 ayat (1) huruf e jo Pasal 32 UU Keperawatan dan Pasal 65 ayat (1) dan ayat (3) UU Tenaga Kesehatan. Pasal 29 ayat (1) huruf e menyebutkan bahwa "dalam menyelenggarakan praktik keperawatan, perawat bertugas sebagai ...e. pelaksana tugas berdasarkan pelimpahan wewenang". Sementara Pasal 65 ayat (1) UU Tenaga Kesehatan menyebutkan bahwa 'dalam melaksanakan pelayanan kesehatan, tenaga kesehatan dapat menerima pelimpahan tindakan medis dari tenaga medis." Kedua pasal tersebut diikuti dengan ketentuan tentang mekanisme dan persyaratan termasuk dampak hukum terhadap beban tanggung jawab yang dihadapi perawat atas tindakan pelimpahan yang dilakukan. Meskipun bila dicermati, ketentuan tentang mekanisme dan persyaratan serta dampak hukum pelimpahan wewenang dari tenaga medis ke tenaga keperawatan yang diatur di dalam Pasal 32 UU Keperawatan mempunyai perbedaan yang cukup signifikan dengan ketentuan yang diatur di dalam Pasal 65 ayat (3) UU Tenaga Kesehatan.

Berdasarkan ketentuan di dalam Pasal 32 UU Keperawatan dapat disimpulkan bahwa: 
1. Pelimpahan wewenang harus dilakukan secara tertulis;

2. Pada akhir pelaksanaan harus dilakukan evaluasi tindakan;

3. Proses pelimpahan dilakukan dalam bentuk delegatif dan/atau mandat;

4. Pada pelimpahan delegatif dibutuhkan persyaratan (a) terlatih; (b) kompeten, (c) adanya peralihan tanggung jawab;

5. Pada pelimpahan mandat diperlukan persyaratan (a) adanya pengawasan; (b)ketiadaan pelimpahan tanggung jawab.

Sementara berdasarkan ketentuan Pasal 65 ayat (3) UU Tenaga Kesehatan pelimpahan wewenang hanya terjadi berdasarkan mandat saja dalam arti tidak ada pelimpahan tanggung jawab. Hal ini tentu saja menimbulkan bias makna di antara kedua undang-undang tersebut karena keduanya mengatur suatu obyek hukum yang sama yakni pelimpahan wewenang menjalankan tindakan medis dari tenaga medis kepada tenaga kesehatan lain yang memiliki kapabilitas (kemampuan) untuk melakukan tindakan tersebut. Adanya ketidakjelasan norma seperti ini justru akan melahirkan ketidakpastian hukum dan kerentaan terhadap perlindungan hukum yang menjadi hak setiap tenaga kesehatan dan masyarakat selaku penerima pelayanan kesehatan, tidak saja kepada perawat selaku tenaga kesehatan yang menerima pelimpahan wewenang, tetapi juga kepada dokter selaku tenaga medis yang memberikan pelimpahan wewenang. Ketidakpastian hukum tentunya hanya akan melahirkan kondisi ketidaknyamanan dalam melakukan profesi yang disandangnya. Dan pada akhirnya ketidaknyaman lingkungan perkerjaan yang demikian akan berujung pada berbagai tindakan dan sikap yang dikenal dengan istilah medicine difense.Tindakan yang terlalu berhati-hati dan bahkan cenderung menghindari berbagai resiko yang mungkin terjadi dari diambilnya tindakan tersebut. Kondisi ini jelas akan berdampak pada kualitas pelayanan kesehatan yang diberikan kepada masyarakat. Sehingga disinilah arti dan fungsi nilai keadilan dalam melandasi keberadaan asas otonomi profesi yang dimiliki perawat dalam menjalankan praktik keperawatannya, di mana slah satunya adalah dengan mendayagunakan hak menolak.

Hak menolak pada konsepnya dapat diartikan sebagai hak yang dimiliki perawat untuk mengajukan penolakan dalam melaksanakan tindakan/tugas di luar kewenangan asuhan keperawatan dan kompetensi individual yang dimilikinya, yang diberikan oleh tenaga kesehatan lain, baik dokter maupun perawat $\operatorname{lain}^{20}$. Namun dalam merealisasikan pemenuhan hak ini diperlukan beberapa persyaratan/kondisi antara lain:

1. Perawat yang menerima pelimpahan tugas tindakan medis/tindakan kesehatan lainnya di luar tindakan asuhan keperawatan, berhak mengajukan penolakan apabila dirasakan dirinya tidak mampu atau tindakan tersebut berada di luar kemampuan diri perawat yang diberikan pelimpahan tugas;

2. Hubungan yang terbentuk antara perawat dengan tenaga kesehatan lain khususnya dokter adalah hubungan hukum yang sejajar/equivallent/sederajat dalam kapasitas/kewenangan masing-masing profesi dan bersifat kooperatif- kolaboratif dan bukan sub-ordinasi.

20 Sebagai suatu perbandingan, di negara-negara maju seperti Singapura dan Amerika Serikat, penyelenggaraan praktik keperawatan dilakukan oleh perawat dengan katagori yang berbeda antara lain Registerd Nurse (RN) dan Advanced Nurse (AN). AN memiliki kualifikasi yang lebih tinggi dibandingkan RN sehingga kewenangan yang dimilikinya pun lebih luas, dan hal ini memungkinkan diterapkannya sistem pelimpahan kewenangan melalui sistem delegasi antara AN kepada RN, dan bukan antara dokter kepada perawat. 
Hubungan hukum yang bersifat koordinasi dimaksudkan sebagai suatu hubungan hukum antara subyek-subyek hukum yang memiliki kewenangan berbeda dalam menjalankan tugas dan fungsi di dalam sistem pelayanan kesehatan tetapi mempunyai kedudukan yang sejajar (equal). Sementara hubungan hukum subordinasi merupakan hubungan hukum dimana kedudukan para pihak di dalamnya dalam keadaan tidak seimbang/tidak sejajar, yang diibaratkan seperti hubungan pekerja dan majikan²1.

Hubungan koordinasi antara perawat dengan rumah sakit dapat dituangkan dalam bentuk perjanjian kerja/perjanjian kontrak antara perawat dan rumah sakit, dalam wujud Hospital by Laws maupun perjanjian individu, tanpa mengabaikan ketentuan Pasal 46 UU Nomor 44 Tahun 2009 tentang Rumah Sakit. ${ }^{22}$ Hospital by law's sebagai suatu peraturan internal RS selama ini terdiri dari 2 (dua) bentuk yakni Hospital by law's sebagai aturan umum dan Medical staff by law's ${ }^{23}$ sebagai aturan internal tentang kedudukan dokter di dalam sistem pelayanan rumah sakit yang mencakup hak, kewajiban serta kewenangan dokter dalam menjalankan praktik kedokterannya yang melahirkan batas-batas tanggung jawab antara dokter dan rumah sakit apabila terjadi suatu kesalahan medis. Dengan lahirnya kesetaraan kedudukan antara perawat dan dokter dalam sistem pelayanan kesehatan tersebut, maka perlu dibentuk adanya pengaturan tersendiri yang memberikan kewenangan kepada perawat dalam menyelenggarakan tugas asuhan keperawatannya kepada klien disertai batas tanggung jawab yang dapat dipikulnya seperti halnya Medical Staff by Law's yang menjadi bagian tak terpisahkan dari Hospital by Law's dan menjadikan perawat sebagai mitra/rekan kerja dokter dalam suatu tin kolaborasi.

Demikian pula hubungan hukum yang terjadi antara perawat dengan tenaga kesehatan lainnya, khususnya dokter, dalam hal ini harus bersifat koordinasi sehingga menempatkan kedua profesi tersebut dalam kedudukan yang sejajar/setara dengan kewajiban dan hak yang diembannya sesuai dengan kewenangan masing-masing profesi. Kesetaraan kedudukan tersebut akan menguatkan pemberdayaan hak otonomi profesi dari perawat yang menjalankan asuhan keperawatan kepada klien, tanpa diperlukan adanya sistem pelimpahan wewenang seperti yang saat ini diatur di dalam Pasal 32 UU Nomor 38 Tahun 2014 tentang Keperawatan dan Pasal 65 UU Nomor 36 Tahun 2014 tentang Tenaga Kesehatan, karena pada prinsipnya pelimpahan wewenang merupakan suatu pemberian kekuasaan dari suatu organ pemerintah yang telah memiliki wewenang tertentu berdasarkan atribusi kepada organ pemerintah lainnya yang akan melaksanakan wewenang yang telah dilimpahkan itu sebagai wewenangnya sendiri ${ }^{24}$. Dengan menerapkan konsep demikian, maka kedudukan perawat tidak lagi dalam suatu kesetaraan tetapi berada di bawah kekuasaan tenaga medis lainnya yang memberikan wewenang tersebut. Di sisi lain, meskipun bidang kesehatan merupakan cakupan ruang lingkup pelayanan publik, yang berarti para penyelenggara di bidang kesehatan tersebut adalah organ pemerintah yang menjalankan pelayanan publik atas nama pemerintah, namun dalam penyelenggaraan praktik kesehatan, adalah hal yang masih menjadi perdebatan mengenai apakah dokter dan/atau perawat yang menjalankan praktik mandiri atau di fasilitas pelayanan kesehatan berbadan hukum swasta dapat dikatakan sebagai organ pemerintah yang menjalankan tugas-tugas negara? Ketidakjelasan status profesi dokter dan perawat dalam suatu sistem pelayanan kesehatan seperti ini tidak mustahil akan menjadi akar dari ketiadaan kepastian hukum bagi penyelenggaraan pelayanan kesehatan/keperawatan itu sendiri.

${ }^{21}$ Gatot S.M. Faisal; 2009; How to be a Smarter Taxpayer, Bagaimana Menjadi Wajib Pajak yang Lebih Cerdas; Jakarta; PT Grasindo; hlm. 60-61

${ }^{22}$ Pasal 46 UU Nomor 44 Tahun 2009 tentang Rumah Sakit menyebutkan bahwa “ rumah sakit bertanggungjawab secara hukum terhadap semua kerugian yang ditimbulkan atas kelalaian yang dilakukan oleh tenaga kesehatan di rumah sakit”

${ }^{23}$ Periksa Peraturan Menteri Kesehatan Republik Indonesia Nomor 727/MENKES/PER/../2002 tentang Hospital by Law's.

${ }^{24}$ Aminuddin Ilmar; 2014; Hukum Tata Pemerintahan; Penerbit Prenamedia Group; Jakarta; hlm. 114 
Apabila hubungan hukum yang terjalin bersifat subordinasi, dimana kedudukan perawat hanya sebagai verlengede arm van de arts (perpanjangan lengan dokter), maka kedudukan perawat akan selalu berada di bawah dokter selaku pihak superior. Dalam keadaan subordinasi yang demikian, akan sulit bagi perawat dalam memberdayakan asas otonomi melalui hak menolak atau hak bertanya karena perawat tidak dalam kedudukan yang setara.

Di sisi lain, asas akuntabilitas sebagai asas yang mencerminkan tanggung gugat perawat dalam melakukan suatu tindakan keperawatan harus dilandasi dengan adanya standar prosedur operasional, standar pelayanan kesehatan, dan standar profesi yang tegas, termasuk di dalamnya adalah standar kompetensi keperawatan yang dibentuk oleh lembaga profesi keperawatan secara mandiri. UU Keperawatan memberikan arah pada adanya asas akuntabilitas melalui keberlakuan kaedah hukum yang mengatur tentang Konsil Keperawatan yang merupakan bagian dari Konsil Tenaga Kesehatan Indonesia, dan organisasi Profesi Keperawatan yakni Persatuan Perawat Nasional Indonesia (PPNI).

\section{F. Kesimpulan}

Pengembangan figur hukum keperawatan sebagai suatu upaya mewujudkan perawat sebagai tenaga kesehatan profesional membutuhkan pengaturan yang berlandaskan pada nilai dan asas hukum yang bertujuan memberikan keadilan, kemanfaatn sekaligus kepastian hukum bagi penyandang profesi perawat dan masyarakat selaku penerima pelayanan kesehatan. Sebagai wujud nilai kemanusian yang menjiwai pelayanan keperawatan, dibutuhkan asas-asas hukum yang mendukung terciptanya keadilan, kemanfaatan,dan kepastian hukum yang selanjutnya dijabarkan dalam norma-norma hukum.

Di samping asas-asas hukum yang tercantum di dalam Undang-Undang Nomor 38 Tahun 2014 tentang Keperawatan, maka diperlukan asas hukum lain yang menopang eksistensi kedudukan profesi perawat dalam kesetaraan dan kesebandingan dengan tenaga kesehatan lain dalam suatu sistem pelayanan kesehatan. Asas-asas yang dimaksud adalah asas otonomi profesi dan asas akuntabilitas.

Asas otonomi profesi dimaksudkan bahwa penyandang profesi perawat mempunyai kebebasan penuh untuk memberikan persetujuan dan/atau penolakannya dalam melakukan suatu tindakan tertentu di luar kompetensinya, yang diperintahkan oleh tenaga kesehatan lain. Sementara asas akuntabilitas dimaksudkan bahwa profesi perawat harus dapat mempertanggungjawabkan semua tindakan keperawatan/kesehatan yang diberikan kepada klien/pasien atas dasar ilmu dan kiat keperawatan.

Kedua asas di atas merupakan turunan (derivasi) dari nilai kesetaraan dan nilai kesebandingan yang melandasi kedudukan perawat dalam sistem pelayanan kesehatan nasional. Kesetaraan diperlukan untuk menempatkan kedudukan perawat dalam sistem pelayanan kesehatan yang melibatkan berbagai tenaga kesehatan dengan berbagai disiplin ilmu yang berbeda. Sementara kesebandingan (proportionality) merujuk pada tanggung jawab yang didasarkan pada hak dan kewajiban (wewenang) yang dimiliki perawat yang berbeda dengan hak dan kewajiban tenaga kesehatan lainnya. Dalam upaya menegakkan nilai kesetaraan dan kesebandingan tersebutlah diperlukan asas otonomi profesi dan asas akuntabilitas profesi sebagai asas hukum yang akan melahirkan norma-norma hukum di dalam suatu perundangundangan yang akan membentuk sistem hukum keperawatan dan sistem hukum pelayanan kesehatan.

Asas otonomi profesi merupakan landasan terbentuknya norma-norma hukum yang melahirkan wewenang (authority) yang di dalamnya terkandung hak dan kewajiban perawat dalam menyelenggarakan pelayanan keperawatan. Salah satu hak yang mendukung asas otonomi tersebut adalah hak menolak. Hak menolak diperlukan dalam mempertahankan kualitas 
keilmuan dan ketrampilan keperawatan dalam memberikan pelayanan kepada pasien/klien berdasarkan kebutuhan perawatan terbaik buat pasien (best interest for patient/client). Sementara asas akuntabilitas dibutuhkan untuk memberikan batasan terhadap tanggung jawab perawat melalui penetapan standard pelayanan kesehatan, standard profesi, dan sistem pengawasan disiplin ilmu keperawatan dalam bentuk pengaturan organisasi profesi.

Asas hukum otonomi dan akuntabilitas pada akhirnya tetap akan berujung pada upaya mewujudkan pelayanan keperawatan yang profesional dan humanistis.

\section{Daftar Pustaka}

Aminuddin Ilmar; 2014; Hukum Tata Pemerintahan; Penerbit Prenamedia Group; Jakarta

Bernard L. Tanya et al; 2013; Teori Hukum, Strategi Tertib Manusia Lintas Ruang dan Generasi; Genta Publishing; Yogyakarta

Bruggink, alih bahasa B. Arief Sidharta; 2011; Reflksi tentang Hukum, Pengertian-Pengertian Dasar dalam Teori Hukum; PT Citra Aditya Bakti; Bandung

Friedman, Lawrence; 1975; The Legal System, A Social Science Perspective; Russel Sage Foundation; New York; ditermahkan M. Khozim; 2011; Sistem, Perspektif Ilmu Sosial; Bandung, PT Nusa Media

Garner, Bryan; Black's Law Dictionary; 1990; 9th edition; WEST Publishing Co; USA

Gatot S.M. Faisal; 2009; How to be a Smarter Taxpayer, Bagaimana Menjadi Wajib Pajak yang Lebih Cerdas; Jakarta; PT Grasindo

Nisya Rifiani \& Hartanti Sulihandari; 2013; Prinsip-Prinsip Dasar Keperawatan; Penerbit dunia Cerdas; Jakarta

Satjipto Rahardjo; 2006; Ilmu Hukum; PT Citra Aditya Bakti; Bandung

Veronika Komalawati; 1999; Peranan Informed Consent Dalam Perjanjian Terapeutik; PT Citra Aditya Bakti; Bandung

Wheeler, Herman; 2012; Law, Ethics And Professional Issues For Nursing; Published by Routledge; New York, USA

\section{Bahan Internet:}

http://www.icn.ch/who-we-are/icn-definition-of-nursing

Bishop, Laura; Ethics Background, Principles; Kennedy Institute of Ethics, Georgetown University; USA; diunduh dari https://www.nwabr.org tanggal 12 februari 2016 , pkl 03.15 WIB

Van Norman, Gail; Informed Consent: Respecting Patient Autonomy; CSA Bulletin; p. 36-46 diunduh dari www.csahq.org/pdf/.../informed_consent tanggal 12 Februari 2016: pkl. 03.34 WIB

Miller-Keane; 2003; Encyclopedia and Dictionary of Medicine, Nursing and Allied Health, 7th edition; diunduh dari http://medical-dictionary.thefreedictionary.com; tanggal 12 Februari 2016 , pkl 03.15 WIB

Short Definitions of Ethical Principles and Theories; American Nurses Association; diunduh dari www.nursingworld.org/.../Ethics-Definitions.pdf tanggal 12 februari 2016, pkl 03.15 WIB

Kant: The Moral Order diunduh dari http://www.philosohypages.com/hy/5i.htm 
von Platz, Jeppe; Autonomy as the Supreme Prinicple of Morality; users.wfu.edu/hardgra/kanteth.html diunduh tanggal 12 februari 2016 , pkl 03.15 WIB

Pellegrini, Edmund.D; Patient aand Physician Autonomy: Conflicting Rights and Obligations in the Physician -Patient Relationships; Journal of Contemporary Health Law and Policy vol. 10:47 p. 47-68, diunduh dari scholarship.law.edu/cgi/viewcontent.cgi/article. tanggal 12 Februari 2016 pkl. 03.30 WIB

\section{Peraturan perundang-undangan}

UU Nomor 12 Tahun 2011 tentang Pembentukan Peraturan Perundang-undangan

UU Nomor 25 Tahun 2009 tentang Pelayanan Publik

UU Nomor 36 Tahun 2009 tentang Kesehatan

UU Nomor 44 Tahun 2009 tentang Rumah Sakit

UU Nomor 36 Tahun 2014 tentang Tenaga Kesehatan

Periksa Peraturan Menteri Kesehatan Republik Indonesia Nomor 727/MENKES/PER/../2002 tentang Hospital by Law's 